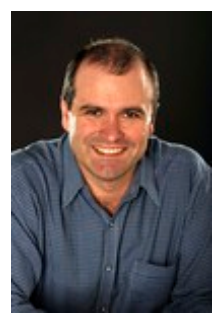

\title{
GREAT BIG HAIRY BEES! \\ REGULATING THE EUROPEAN BUMBLEBEE, BOMBUS \\ TERRESTRIS L. WHAT DOES IT SAY ABOUT THE PRECAUTIONARY PRINCIPLE?*
}

\section{Cameron Moore}

Lecturer, School of Law, University of New England

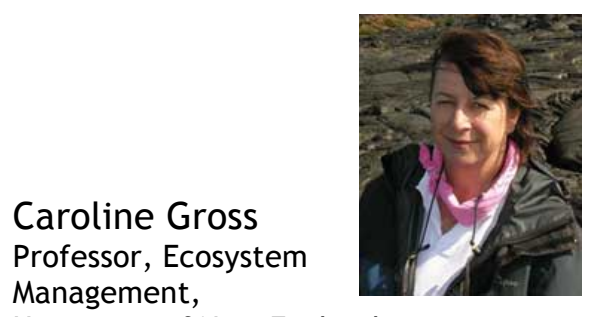

University of New England

The previous Commonwealth Minister for the Environment, Mr Garrett, rejected a request to allow the importation of live bumblebees (Bombus terrestris L.) to mainland Australia. New South Wales and Victoria had already listed the introduction of bumblebees as, respectively, a key threatening process and a potentially threatening process. The Commonwealth, however, had previously declined an application to list the introduction of bumblebees as a key threatening process, although its Threatened Species Scientific Committee urged 'that extreme caution be shown in considering any proposal to introduce this species to the mainland.' The potential threat from bumblebees would appear to beg the questions posed by the precautionary principle. Would the presence of bumblebees to mainland Australia pose a threat of serious or irreversible environmental damage? Should a lack of full scientific certainty be used as a reason for postponing measures to prevent environmental degradation? This paper considers the role of the precautionary principle in regulatory approaches to the bumblebee. It seeks to establish the application of the precautionary principle to this particular potential environmental threat, including its relationship to the principle of conservation of biological diversity. It concludes that, despite widespread adoption of the precautionary principle in policy, legislation and case law in Australia, its impact on regulating bumblebees has not been consistent.

\section{Introduction}

The previous Commonwealth Minister for the Environment, Mr Garrett, rejected a request to allow the importation of live bumblebees to Australia. He said that the 'introduction of alien species into Australia can have serious environmental consequences' and that national environmental legislation required him to take a precautionary approach. ${ }^{1}$

Australia is considered a mega-diverse region with high levels of endemism (uniqueness) within the estimated 20000 flowering plant species, ${ }^{2} 6775$ species of vertebrate, an esti-

\footnotetext{
* The authors would like to acknowledge gratefully the assistance of Dr Chris McGrath, Barrister-at-Law, Brisbane, in providing comments on the paper, and Professor David Farrier and Dr Warwick Gullett of the University of Wollongong. and Professor Paul Martin, Director of the AgLaw Centre, UNE for their comments on earlier drafts.

${ }^{1}$ The Hon Peter Garrett MP, Minister for the Environment, Heritage and the Arts, 'Bumblebee Rejected for Live Import' (Media Release, 26 October 2008).

${ }^{2}$ A Sjöström and C L Gross, 'Life-History Characters and Phylogeny are Correlated with Extinction Risk in the Australian Angiosperms' (2006) 33 Journal of Biogeography 271.
} 
mated 240000 species of invertebrate and an unquantified number of micro-organisms. ${ }^{3}$ The flotilla of Gondwanan species and the subsequent isolation of the island continent from other biotas about 170 million years before present has shaped this diversity and has been the impetus for much community structure in the form of co-evolved mutualisms (that is, co-dependant relationships, for example the plant-pollinator interface).

Weeds and feral animals are one of the major pressures on Australian biodiversity. ${ }^{4}$ The recent migration (over the last 200 years) of invasive species to Australia (for example, of about 2500 plant species) jeopardises the persistence of many native species, ecosystems and evolutionary processes. Australia has many prominent examples of the extreme ecological, social and economic damage that deliberate introductions can cause. Cane toads, prickly pear, red foxes, rabbits and bitou bush are just a few of the invasive species that the Commonwealth government now spends millions of dollars trying to contain. ${ }^{5}$ Coupled with the significant impacts of habitat modification, it is concomitant that almost one quarter of the world's recently extinct species comes from Australia. ${ }^{6}$ The ecological, social and economic damage caused by invasive species is recognised by all tiers of Government - as exemplified by local noxious weed declarations, ${ }^{7}$ threatening processes regimes at state level ${ }^{8}$ and robust quarantine and importation laws at the Commonwealth level. ${ }^{9}$

The European bumblebee (Bombus terrestris L.) (Hymenoptera: Apidae)) does not occur on the Australian mainland but was introduced to the island of Tasmania about 18 years ago where it is now widespread and abundant. ${ }^{10}$ The Australian Hydroponic and Greenhouse Association sought a permit for the importation of live bumblebees ${ }^{11}$ to mainland Australia to facilitate the pollination of crops, particularly greenhouse tomatoes (Solanum lycopersicum).${ }^{12}$ However, if bumblebees escape from greenhouses and establish in the wild in mainland Australia they can cause both ecological and economical harm. This could occur through competition for nectar and pollen with native animals and commercial honeybees, reduced seed production and altered gene flow in native plants, as well as increased seed production in weeds. ${ }^{13}$ In Tasmania and New Zealand many of these perturbations have already happened as a result of bumblebee incursions throughout urban, agricultural and natural habitats. ${ }^{14}$

New South Wales and Victoria have listed the introduction of bumblebees as, respectively, a key threatening process (KTP) or a potentially threatening process (PTP). The Draft Vic-

\footnotetext{
${ }^{3}$ See Commonwealth Department of Environment and Water, Australian Faunal Directory: Estimated Numbers of the Australian Fauna (15 August 2007) Environment <http://www.deh.gov.au/biodiversity/abrs/onlineresources/fauna/afd/stats-est.html>; A J Beattie, Australia's Biodiversity Living Wealth: Exploring Australia's Plants, Animals and Micro-Organisms (Reed Books, 1995), 1.

${ }^{4}$ See R J S Beeton, K I Buckley, G J Jones, D Morgan, R E Reichelt, D Trewin, Australian State of the Environment 2006 (2006) Australian State of the Environment Committee, <http://www.environment.gov.au/soe/2006/publications/report/biodiversity-2.html\#weeds>.

${ }^{5}$ T Low, Feral Future (Viking, 1999), 1. As noted by Sinden et al. (2004) the cost of weeds to Australian agriculture now exceeds $\$ 4$ billion a year. (J Sinden, R Jones, $\mathrm{S}$ Hester, D Odum, C Kalish, R James and $\mathrm{O}$ Cacho, The Economic Impact of Weeds in Australia, 'Technical Series No. 8, Report to the CRC for Australian Weed Management', Adelaide, 2004).

${ }^{6}$ K S Walter and H J Gillet, 1997 IUCN Red List of Threatened Plants (Cambridge: IUCN, World Conservation Union, 1998).

${ }^{7}$ For example, Noxious Weeds Act 1993 (NSW).

${ }^{8}$ Discussed below.

${ }^{9}$ Quarantine Act 1908 (Cth).

${ }^{10}$ A B Hingston et al, 'Extent of Invasion of Tasmanian Native Vegetation by the Exotic Bumblebee Bombus terrestris (Apoidea: Apidae)' (2002) 27 Austral Ecology 162.

${ }^{11}$ Australian Hydroponic and Greenhouse Association, below n 112.

${ }^{12}$ A B Hingston, 'Does the Introduced Bumblebee, Bombus terrestris (Apidae), Prefer Flowers of Introduced or Native Plants in Australia?' (2005) 53 Australian Journal of Zoology 29; S Carruthers, 'Editorial’ (2003) 69 Australian Hydroponics 24.

${ }^{13}$ Hingston, ibid, 29-34; S R Simpson et al, 'Broom and Honeybees in Australia: An Alien Liaison' (2005) 7 Plant Biology 541.

${ }^{14}$ Hingston et al, above n 10, 162-172.
} 
torian Action Statement on bumblebees states that a 'precautionary approach to the introduction of bumblebees must be taken. ${ }^{15}$ Curiously, the Commonwealth Threatened Species Scientific Committee had declined an application to list the introduction of bumblebees as a KTP. Even so, it urged 'that extreme caution be shown in considering any proposal to introduce this species to the mainland'. ${ }^{16}$

The potential threat posed by bumblebees appears to beg the questions posed by the precautionary principle, which s 391(2) of the Environment Protection and Biodiversity Conservation Act 1999 (Cth) ('EBCD Act') puts thus:

The precautionary principle is that lack of full scientific certainty should not be used as a reason for postponing a measure to prevent degradation of the environment where there are threats of serious or irreversible environmental damage.

Would the presence of bumblebees in mainland Australia pose a threat of serious or irreversible environmental damage? Should a lack of full scientific certainty be used as a reason for postponing measures to prevent environmental degradation? This paper considers the role of the precautionary principle in the regulatory approaches to the bumblebee of the New South Wales, Victorian and Commonwealth jurisdications. The issue of importation and use of bumblebees has not been before a court or tribunal so the focus is on the regulatory approaches. As Fisher, Jones and von Schomberg note, 'there have been few empirical studies of the (precautionary) principle in operation' and this paper aims to contribute to filling this gap. ${ }^{17}$ Upon examination of the regulatory approach of each jurisdiction, it is possible to say that the precautionary principle has had a role to play but it is far from consistent and much less significant than the principle of conservation of biological diversity. It seems decisive with respect to importation and quite elusive with respect to listing as a threatening process. The paper concludes that, despite the widespread adoption of the precautionary principle into policy, legislation and case law in Australia, its effect on regulating the impact of a threatening species like the bumblebee is not as significant as might be expected.

This paper will examine briefly the widespread adoption of the precautionary principle. The paper will then consider its place with respect to the New South Wales, Victorian and Commonwealth threatening process provisions. The paper will then address the threat of bumblebees and the various scientific committee responses to it. It will then turn to the application of the precautionary principle to the application for the import of bumblebees.

\footnotetext{
${ }^{15}$ Introduction of the Large Earth Bumblebee (3 November 2008) Flora and Fauna Guarantee - Draft Action Plans for Public Comment, 3 <http://www.dse.vic.gov.au/DSE/nrenpa.nsf/LinkView/69770772A2A1F48BCA256 FB300073432E7A24BB36FF60A144A256DEA00244294>

${ }^{16}$ Commonwealth Threatened Species Scientific Committee 'Changes to Plant-Pollinator Associations Caused by Large Earth Bumblebees, Bombus spp.' (Advice to the Minister for Environment and Heritage from the Threatened Species Scientific Committee on a public nomination of a Key Threatening Process under the Environment Protection and Biodiversity Conservation Act 1999, 2008), Recommendation C, <http: //www.environment. gov.au/biodiversity/threatened/ktp/bumblebees.html>

17 Elizabeth Fisher, Judith Jones and Rene von Schomberg, 'Implementing the Precautionary Principle: Perspectives and Prospects' in Elizabeth Fisher, Judith Jones and Rene von Schomberg (eds), Implementing the Precautionary Principle: Perspectives and Prospects (Edward Elgar Publishing Ltd, 2006), 6. See also Deborah Peterson, 'Precaution: Principles and Practice in Australian Environmental and Natural Resource Management' (2006) 50 The Australian Journal of Agricultural and Natural Resource Economics 469, 469-470; Justice Paul Stein, 'Are Decision-makers too Cautious with the Precautionary Principle?' (2000) 17(3) Environmental and Planning Law Journal 20; and Jeff Smith, 'Skinning Cats, Putting Tigers in Tanks and Bringing Up Baby: A Critique of the Threatened Species Conservation Act 1995 (NSW)' (1997) 14 Environmental and Planning Law Journal 17, 26.
} 


\section{The pervasiveness of the precautionary principle}

The general development and adoption of the precautionary principle in Australia has been well traversed by Justice Stein, ${ }^{18}$ Peel, ${ }^{19}$ Gullett, ${ }^{20}$ Peterson, ${ }^{21}$ Deville and Harding ${ }^{22}$ and others. This paper will not seek to repeat their work but rather briefly state the apparent breadth of adoption of the principle and set out some theoretical issues for examination of the bumblebee question.

A brief overview of the international development of the precautionary principle is useful to understanding its Australian manifestations. While the 1972 Declaration of the United Nations Conference on the Human Environment (the 'Stockholm Convention') is seen as the beginning for the precautionary principle in international law, ${ }^{23}$ it has been more widely articulated through the Rio Declaration of the United Nations Conference on Environment and Development (the 'Rio Declaration') in 1992. Principle 15 of the Rio Declaration states:

In order to protect the environment, the precautionary approach shall be widely applied by States according to their capabilities. Where there are threats of serious or irreversible damage, lack of full scientific certainty shall not be used as a reason for postponing cost-effective measures to prevent environmental degradation. ${ }^{24}$

In Australia the precautionary principle is widely mentioned or articulated in both Commonwealth and state legislation, usually as a core principle of ecologically sustainable development (ESD). ${ }^{25}$ In 1990 a special premiers' conference took place in Brisbane where the Commonwealth, states, territories and representatives of local government agreed to develop an Intergovernmental Agreement on the Environment (IGAE). Within the IGAE, the various jurisdictions agreed that certain specified principles should inform policy-making and program implementation, including the precautionary principle as follows:

\subsection{1 precautionary principle -}

Where there are threats of serious or irreversible environmental damage, lack of full scientific certainty should not be used as a reason for postponing measures to prevent environmental degradation. In the application of the precautionary principle, public and private decisions should be guided by:

i careful evaluation to avoid, wherever practicable, serious or irreversible damage to the environment; and

li an assessment of the risk-weighted consequences of various options. ${ }^{26}$

The IGAE was fundamental to ensuring the passage of the EPBC Act because it provided a national policy position upon which to base Commonwealth reform. ${ }^{27}$ The Commonwealth

\footnotetext{
${ }^{18}$ Ibid 3-5, notably His Honour discusses a Danish bee case with respect to the precautionary principle but it concerned whether prohibiting all bees from an island apart from a certain sub-species of indigenous bee, Apis mellifera mellifera (the Laeso Brown Bee), in order to protect the indigenous bee, was contrary to European trade law. Usefully though, His Honour states that the European Court of Justice took a precautionary approach to the conservation of biodiversity.

19 Jacqueline Peel, The Precautionary Principle in Practice: Environmental Decision-Making and Scientific Uncertainty (Federation Press 2005).

${ }^{20}$ See Warwick Gullett "Environment Protection and the "Precautionary Principle": A Response to Scientific Uncertainty in Environmental Management' (1997) 14 Environmental and Planning Law Journal 52, 55 (for its international development) and 61-4 (for its early Australian development).

${ }^{21}$ See discussion in Peterson, above $\mathrm{n}$ 17, 478-482.

${ }^{22}$ Adrian Deville and Ronnie Harding, Applying the Precautionary Principle (Federation Press, 1997).

${ }^{23}$ Declaration of the United Nations Conference on the Human Environment (1972) 11 ILM 1416. See D E Fisher Australian Environmental Law (Thomson Reuters, 2003), 58-59.

${ }^{24}$ Declaration of the United Nations Conference on Environment and Development (1992) 31 ILM 874.

${ }^{25}$ See Peel, above $\mathrm{n} 19$, Appendix A: Australian legislation incorporating the precautionary principle.

${ }^{26}$ The IGAE forms a Schedule to the National Environment Protection Council Act 1994 (Cth).

${ }^{27}$ Commonwealth, Bills Digest No. 135 1998-99 Environment Protection and Biodiversity Conservation Bill 1998 (Cth) <http://parlinfoweb.aph.gov.au/piweb//view_document.aspx?TABLE=BILLSDGS\&ID=2619>
} 
implemented aspects of it by making ESD an object of the Act at s 3 , and then providing, in a more limited way than in the IGAE, at s $3 \mathrm{~A}$ that:

The following principles are principles of ecologically sustainable development:

(b) if there are threats of serious or irreversible environmental damage, lack of full scientific certainty should not be used as a reason for postponing measures to prevent environmental degradation;

As mentioned above, the Act actually defined the precautionary principle at s 391(2) in essentially the same words but in a different order. Victoria and New South Wales have also legislated for the precautionary principle and this paper addresses the relevant provisions below.

As well as legislation, there is now a fairly substantial body of case law on the precautionary principle, ${ }^{28}$ extending beyond the oft cited Leatch $v$ National Parks and Wildlife Service ('Leatch'), ${ }^{29}$ Nicholls v Director General of National Parks and Wildlife Service, ${ }^{30}$ Greenpeace Australia Ltd $v$ Redbank Power Co Pty Ltd ${ }^{31}$ and Friends of Hinchinbrook Society Inc $v$ Minister for Environment..$^{32}$ The precautionary principle was considered in two 2006 cases on the EPBC Act. ${ }^{33}$ Wildlife Preservation Society of Queensland Proserpine/Whitsunday Branch Inc $v$ Minister for the Environment \& Heritage \& Ors, ('the Queensland Coal Mines Case'), raised, though did not apply the precautionary principle, ${ }^{34}$ and Brown $v$ Forestry Tasmania ${ }^{35}$ mentioned it but did not turn on the principle. Preston CJ of the New South Wales Land and Environment Court provided a thorough analysis of ESD and the precautionary principle in 2006 in Telstra $v$ Hornsby Shire Council. ${ }^{36} \mathrm{His}$ Honour also saw all the principles of ESD as relevant to the seriousness of an offence under the Threatened Species Conservation Act 1995 (NSW)when sentencing. ${ }^{37}$ Notably the decision in Gray $v$ The Minister for Planning and Ors, ('Anvil Hill Case') $)^{38}$, adopted Preston $\mathrm{CJ}$ 's reasoning and extended the application of the precautionary principle to global warming. ${ }^{39}$

The key point to be made here is that the precautionary principle appears widely in Australian policy, legislation and case law, so it might be expected to have an impact on the regulation of bumblebees.

\section{To what extent was each committee bound to apply the precau- tionary principle?}

To begin assessing the impact of the precautionary principle on regulating bumblebees, it is necessary to consider the extent to which each scientific committee is actually bound to apply the precautionary principle in its decision making before turning to the actual listing

\footnotetext{
${ }^{28}$ See Peel, above n 19, Appendix C: Cases Considering the Precautionary Principle.

${ }^{29}$ Leatch v National Parks and Wildlife Service (1993) 81 LGERA 270.

${ }^{30}$ Nicholls $v$ Director General of National Parks and Wildlife Service (1994) 84 LGERA 397.

${ }^{31}$ Greenpeace Australia Ltd $v$ Redbank Power Co Pty Ltd (1994) 86 LGERA 143.

${ }^{32}$ Friends of Hinchinbrook Society Inc v. Minister for Environment and others [1997] FCA 55 (14 February 1997); on appeal Friends of Hinchinbrook Society Inc $v$ Minister for the Environment and others [1997] 789 FCA (6 August 1997); see also Friends of Hinchinbrook Society Inc v Minister for the Environment (1997) ALR 142632.

${ }^{33}$ For a more general discussion of recent EPBC Act cases, see Greg Prutej, 'Commonwealth Environment and Heritage Law' AGS Legal Briefing, Advance issue, 18 April 2007.

${ }^{34}$ Wildlife Preservation Society of Queensland Proserpine/Whitsunday Branch Inc v Minister for the Environment \& Heritage \& Ors [2006] FCA 736, para 54.

${ }^{35}$ Brown v Forestry Tasmania (No 4) [2006] FCA 1729, see paras 222, 223 \& 232.

${ }^{36}$ Telstra Corporation Ltd v Hornsby Shire Council [2006] NSWLEC 133, paras 107-188, considered in Telstra Corporation Ltd v Holroyd City Council [2006] NSWLEC 527 and Telstra Corporation Limited v Campbelltown City Council [2006] NSWLEC 762, which also concerned issues of radiofrequency emissions from mobile telephone towers in residential areas.

${ }^{37}$ Bentley v BGP Properties Pty Limited [2006] NSWLEC 34, paras 171-172.

${ }^{38}$ Gray $v$ The Minister for Planning and Ors [2006] NSWLEC 720, see paras 109, 114, 127-135 \& 145.

${ }^{39}$ See the Queensland Coal Mines Case paras 53-69. This case was decided in June 2006 and the Anvil Hill Case in November 2006. The Anvil Hill Case considered and distinguished the Queensland Coal Mines Case.
} 
processes of each jurisdiction in question. This will illustrate how elusive the precautionary principle is with respect to listing decisions on the bumblebee. The Victorian and Commonwealth committees were not bound to consider it, and it is only arguable that the New South Wales committee could have been bound to consider it.

\section{Victoria}

As discussed below, the legislation that authorises listing of a PTP in Victoria is the Flora and Fauna Guarantee Act 1988 (Vic). There is no reference to the precautionary principle in this Act, perhaps because it was first enacted in 1988 before the precautionary principle attained general application in Australia. Rather, the Environment Protection Act 1970 (Vic) provides as follows:

1C. The precautionary principle

(1) If there are threats of serious or irreversible environmental damage, lack of full scientific certainty should not be used as a reason for postponing measures to prevent environmental degradation.

(2) Decision making should be guided by-

(a) a careful evaluation to avoid serious or irreversible damage to the environment wherever practicable; and

(b) an assessment of the risk-weighted consequences of various options.

In the absence of any reference between the acts in question, it cannot be said that the precautionary principle applies to decisions made under the Flora and Fauna Guarantee Act. It may arguably be a 'common sense' relevant consideration to such decisions as was the case in the New South Wales case of Leatch. ${ }^{40}$ The authors have been unable to find any Victorian case though that would be authority for the proposition that the precautionary principle was a relevant consideration. It could still be open to argue this upon general principles of administrative law but it is important to note that the empowering statute primarily determines what the decision maker is bound to consider. ${ }^{41}$ The precautionary principle could then be a relevant consideration, but not necessarily a binding one. As far as listing a PTP is concerned, sch 1 of the Flora and Fauna Guarantee Regulations 2001 sets out the criteria for determining a listing recommendation. The language of these criteria is at least reflective of the precautionary principle and this is discussed below.

\section{New South Wales}

The Threatened Species Conservation Act 1995 (NSW) has as its first object in s 3 'to conserve biological diversity and promote ecologically sustainable development'. Section 4 of the Act provides that ecologically sustainable development has the same meaning as in the Protection of the Environment Administration Act 1991 (NSW), which, at s 6, includes the precautionary principle in quite similar words to the Victorian provision thus:

(2)... (a) the precautionary principle-namely, that if there are threats of serious or irreversible environmental damage, lack of full scientific certainty should not be used as a reason for postponing measures to prevent environmental degradation. In the application of the precautionary principle, public and private decisions should be guided by:

(i) careful evaluation to avoid, wherever practicable, serious or irreversible damage to the environment, and

(ii) an assessment of the risk-weighted consequences of various options,

While this may be so, there is no specific requirement under pt 2 of the Act, or the Threatened Species Conservation Regulation 2002, concerning listing, for the Scientific

\footnotetext{
${ }^{40}$ Leatch v National Parks and Wildlife Service (1993) 81 LGERA 270, 282.

${ }^{41}$ Minister for Immigration and Multicultural Affairs v Yusuf (2001) 206 CLR 323, 347-348.
} 
Committee to take ESD or the precautionary principle into account. Section 97 of the Act concerning licensing however does require the Director-General to take the principles of ESD into account in making licensing decisions. The lack of a similar specific requirement with respect to listing would suggest that the Act does not require principles of ESD to be taken into account in listing decisions. Leatch could apply, though, to make the precautionary principle a relevant consideration. Further, Preston CJ stated plainly in Telstra $v$ Hornsby Shire Council:

The principles of ecologically sustainable development are to be applied when decisions are being made under any legislative enactment or instrument which adopts the principles. ${ }^{42}$

Arguably, then, the objects of the Threatened Species Conservation Act may be enough to require the New South Wales Scientific Committee to apply the precautionary principle in its decision making, despite the clear omission of a requirement to do so in the listing provisions. ${ }^{43}$ This is only arguable, though, and it cannot be said with certainty that the New South Wales Scientific Committee is bound to take the precautionary principle into account in listing decisions. Whelan, Brown and Farrier ${ }^{44}$ note that, in NSW, a more thorough application of the precautionary principle is needed in assessing impacts on endangered species, as currently the lack of full scientific certainty is often used to imply that there are no detrimental impacts.

\section{The Commonwealth}

Sperling's view is that the precautionary principle does not have sufficient bearing on the biodiversity conservation provisions of the EPBC Act. She stated, on a preliminary assessment of the Act, that 'The legislation is therefore largely irrelevant to this discussion of the type of law which needs to exist if caution [ie the precautionary principle] really matters' ${ }^{45}$ An examination of the Act bears this out, at least with respect to listing processes.

For Commonwealth Threatened Species Scientific Committee recommendations to the Minister on listing, s 189(3) of the EPBC Act provides that the Scientific Committee must not consider any matter that does not relate to the survival of the native species or ecological community concerned. ${ }^{46}$ The precautionary principle could be relevant to such matters but clearly the Scientific Committee is not bound to consider it as such.

There is no direct obligation on the Commonwealth Minister either to consider the precautionary principle with regard to a recommendation from the Scientific Committee for listing a KTP. The EPBC Act makes clear when the Minister must take it into account. The Act provides:

\section{Minister must consider precautionary principle in making decisions}

Taking account of precautionary principle

\footnotetext{
${ }^{42}$ Telstra Corporation Ltd v Hornsby Shire Council (2006) NSWLEC 133, para 121 citing Murrumbidgee GroundWater Preservation Association v Minister for Natural Resources [2004] NSWLEC 122 (7 April 2004) at [178]; and Bentley v BGP Properties Pty Ltd [2006] NSWLEC 34 (6 February 2006) at [57].

${ }^{43}$ See discussion by Sue Mahoney in "Efficacy of the "Threatening Processes" Provisions in the Threatened Species Conservation Act 1995 (NSW): Bush-rock Removal and the Endangered Broad-Headed Snake' (1997) 14 (3) Environmental and Planning Law Journal 12. Karla Sperling noted in 1999 that there was no provision which made a precautionary approach to biodiversity conservation mandatory in NSW, 'If Caution Really Mattered' 16 (5) Environmental and Planning Law Journal 425, 435. The objects of the Act may be most relevant where there is a question of statutory interpretation of the Act.

${ }^{44}$ R J Whelan, C L Brown and D Farrier, 'The Precautionary Principle: What is it and How Might it be Applied in Threatened Species Conservation?' in Pat Hutchings, Daniel Lunney and Chris Dickman (eds) Threatened Species Legislation: Is it Just an Act? (Mosman NSW, Royal Zoological society of New South Wales, 2004) 49.

${ }^{45}$ Sperling, above $\mathrm{n} 43,440$.

${ }^{46}$ This is consistent with the view of the Senate Committee Report on the legislation noted below at $\mathrm{n} 51$. There is also nothing in ss 502 or 503 , regarding the establishment and functions of the Committee, on the precautionary principle or the objects of the Act.
} 
(1) The Minister must take account of the precautionary principle in making a decision listed in the table in subsection (3), to the extent he or she can do so consistently with the other provisions of this Act.

There is no reference in the table in sub-s (3) of s 391 to the sections dealing with listing Key Threatening Processes.

Given the object of ecologically sustainable development in s 3 of the Act, it is open to argue that the precautionary principle is a relevant consideration as understood in Leatch $\checkmark$ Director-General of National Parks and Wildlife Service. ${ }^{47}$ Sackville $\mathrm{J}$ left this possibility open in Friends of Hinchinbrook Society Inc $v$ Minister for Environment. ${ }^{48}$ The authors could find no High Court or Federal Court case, though, that would be authority for the proposition of Preston CJ in Telstra $v$ Hornsby Shire Council, discussed above, on the requirement to apply ESD principles in decisions under legislation which adopts such principles. Given the clear omission of the precautionary principle from the listing provisions, it is not possible to say that it must apply to listing decisions.

\title{
Biodiversity conservation as the real focus?
}

If the precautionary principle has at best only indirect effect, is it that biodiversity conservation is really the most relevant principle to the provisions guiding the various committees' decisions? ${ }^{49}$ Preston CJ stated in Telstra $v$ Hornsby Shire Council:

\begin{abstract}
The precautionary principle is but one of the set of principles of ecologically sustainable development (highlighted earlier in the judgment). It should not be viewed in isolation, but rather as part of the package. This means that the precautionary measures that should be selected must not only be appropriate having regard to the precautionary principle itself, but also in the context of the other principles of ecologically sustainable development including inter-generational and intra-generational equity and the conservation of biological diversity and ecological integrity. ${ }^{50}$
\end{abstract}

This is perhaps a reason that the precautionary principle is not a binding consideration in the various listing provisions, because they are actually biodiversity conservation provisions. Even though it should be part of the balance of ecologically sustainable development, biodiversity conservation is a distinct principle of environmental law that is not always seen as compatible with it. Biodiversity conservation is an explicit or implicit object of the relevant acts, as much (if not more) than ecologically sustainable development or the precautionary principle. Smith notes that in the Threatened Species Conservation Act biodiversity is elevated alongside ESD 'as an end in itself as well as a mechanism for achieving the overall notion of sustainability'. Indeed, the Senate Committee in the Environment Protection and Biodiversity Conservation Bill 1998 preferred ESD not to be a purpose of the listing process, as it could potentially dilute the focus on survival of species. ${ }^{51}$ Farrier sees the narrow biodiversity focus of the Flora and Fauna Guarantee Act as even being contrary to the precautionary principle because, referring to s 11, it requires 'demonstrable' states of decline and 'likely' extinction before listing. ${ }^{52}$ Nonetheless, the precautionary principle's 'threats of serious or irreversible environmental

\footnotetext{
${ }^{47}$ As well as being relevant to statutory construction.

${ }^{48}$ Friends of Hinchinbrook Society Inc v. Minister for Environment and others [1997] FCA 55 (14 February 1997).

${ }^{49}$ Smith, above n 17, 24.

50 Telstra Corporation Ltd v Hornsby Shire Council [2006] NSWLEC 133, para 182, citing A Deville and R Harding, Applying the Precautionary Principle, (Federation Press, 1997) 43.

${ }^{51}$ Commonwealth, Senate Environment, Communications, Information Technology and the Arts Committee Report on Environment Protection and Biodiversity Conservation Bill 1998 \& Environmental Reform (Consequential Provisions) Bill 1998, Chapter 11 <http://www.aph.gov.au/senate/committee/ecita_ctte/ completed_inquiries/1999-02/bio/report/c11.htm>

52 David Farrier 'Factoring Biodiversity Conservation into Decision Making Processes: The Role of the Precautionary Principle' in Ronnie Harding and Elizabeth Fisher (eds), Perspectives on the Precautionary Principle (Federation Press, 1999) 99, 112.
} 
harm' and 'measures to prevent environmental degradation' appear very pertinent to listing threatening processes. ${ }^{53}$ In fact, Leatch, which led the consideration of the precautionary principle in Australian courts, concerned conservation of biological diversity. ${ }^{54}$ The precautionary principle is a part of the preamble of the Convention on Biological Diversi$t y^{55}$ itself and, as Cooney states:

The precautionary principle is of immediate and widespread relevance in the biodiversity context: indeed, it has been argued that it applies to biodiversity more than to any other environmental problem, due to the dramatic and irreversible nature of current extinction patterns. ${ }^{56}$

Rather than the precautionary principle being seen as distinct and even incompatible with biodiversity conservation, it might be expected then that the various legislative provisions on listing threatening process could have explicitly incorporated it. As it is, they have not, and a biodiversity conservation focus in the relevant legislative provisions may explain why the precautionary principle, even though apparently relevant, has no direct impact on state decisions concerning bumblebees. It is appropriate to turn now to the threat of the bumblebee and the various scientific committee responses to it. ${ }^{57}$

\section{Bumblebees as a threatening process}

\section{The Large Earth Bumblebee, 'Bombus Terrestris L.'}

The Bumblebee (Bombus Terrestris L.) is native to Europe and North Africa ${ }^{58}$ but has been deliberately distributed around the world for the pollination of field crops - as early as 1885 to New Zealand ${ }^{59}$ and a century later, as the technology developed, as a domesticated pollinator for the production of greenhouse tomatoes. ${ }^{60}$

Bumblebees have escaped from their agricultural environments and have established as a feral species in many countries including New Zealand, ${ }^{61}$ Chile, ${ }^{62}$ Israel, ${ }^{63} \mathrm{Japan}^{64}$ and Mexico. ${ }^{65}$ Bumblebees appeared in Tasmania in February 1992, ${ }^{66}$ and are now ubiquitous in urban and natural habitats throughout the island state. ${ }^{67}$ There is compelling evidence

${ }^{53}$ See Freya Dawson 'Analysing the Goals of Biodiversity Conservation: Scientific, Policy and Legal Perspectives' (2004) 21 (6) Environmental and Planning Law Journal 6, particularly 19-20.

${ }^{54}$ In that case, a threat to rare flora and fauna due to the construction of a road and bridge.

${ }^{55}$ Convention on Biological Diversity, opened for signature 5 June 1992, 1760 UNTS 79 (entered into force 29 December 1993).

${ }^{56}$ Rosie Cooney 'A Long and Winding Road? Precaution from Principle to Practice in Biodiversity Conservation' in Fisher, Jones and von Schomberg (eds), above n 17, 223, 224.

${ }^{57}$ See Angela Dwyer, 'Species Listing and Precaution under the Environment Protection and Biodiversity Conservation Act 1999 (Cth)' (2006) (Paper presented at the ALTA Legal Knowledge: Learning, Communicating and Doing Conference, Melbourne, Australia, July 2006).

${ }^{58}$ C D Michener, The Bees of the World (John Hopkins University Press, 2000); T Ings et al, 'Bumblebees, Humble Pollinators or Assiduous Invaders? A Population Comparison of Foraging Performance in Bombus terrestris' (2005) 144 Oecologia 508

${ }^{59}$ R P Macfarlane and L Gurr 'Distribution of Bumble Bees in New Zealand' (1995) New Zealand Entomologist 18, 29-36.

${ }^{60} \mathrm{H} \mathrm{H}$ W Velthuis, The Historical Background of the Domestication of the Bumble-Bee, Bombus terrestris, and its Introduction in Agriculture (Ministry of Environment, Sao Paola Brazil, 2002) 177.

${ }^{61}$ Macfarlane and Gurr, above n 59, 29-36.

${ }^{62} \mathrm{~L}$ Ruz and R Herrera, 'Preliminary Observations on Foraging Activities of Bombus dahlbomii and Bombus terrestris (Hym: Apidae) on Native and Non-Native Vegetation in Chile' (2001) 561 Acta Horticulturae 165.

${ }^{63}$ A Dafni and A Shmida 'The Possible Ecological Implications of the Invasion of Bombus terrestris (L.) (Apidae) at Mt Carmel, Israel' in A Matheson et al (eds) The Conservation of Bees (Academic Press, 1996) 183-200.

${ }^{64}$ Matsumara et al, cited in T C Ings et al, above n 58, 508-516.

${ }^{65}$ D Goulson, 'Effects of introduced bees on native ecosystems' (2003) 34 Annual Review of Ecology Evolution and Systematics 1-26.

${ }^{66}$ T D Semmens, E Turner, R Buttermore, 'Bombus terrestris (L.) (Hymenoptera: Apidae) Now Established in Tasmania' (1993) 32(4) Journal of the Australian Entomological Society 346.

${ }^{67}$ Hingston et al (2002), above $\mathrm{n} 10,162-172$. 
that bumblebees are causing irreparable environmental damage in Tasmania, ${ }^{68}$ and that the proliferation of weeds and sleeper weeds will be exacerbated by the bumblebee's superior foraging behaviour on co-evolved Mediterranean weeds. ${ }^{69}$ The precedent for perturbation by a non-native pollinator has also been clearly established on the mainland with introduced honeybees (Apis mellifera), which can reduce seed production in native species, ${ }^{70}$ affect seed production in some native species ${ }^{71}$ and set seed in weeds that would otherwise be barren. ${ }^{72}$

\section{The listing, or not, of introduction of bumblebees as a threatening process}

The governments of New South Wales and Victoria have independently determined the risk of bumblebees to be such that they have declared foraging by bumblebees to be a KTP in New South Wales and a PTP in Victoria - though the species is yet to colonise these mainland areas. ${ }^{73}$ The Commonwealth declined a similar application in 2002-2003 on the basis that there was not enough scientific evidence to support the applicant's contention that foraging by bumblebees would be a KTP. ${ }^{74}$ It is interesting to note that the unsuccessful applicant to the Commonwealth Government (Dr Andrew Hingston, University of Tasmania) was successful in both applications to the states of New South Wales and Victoria.

\section{The Victorian Listing}

In Victoria, the Flora and Fauna Guarantee Act 1988 ('FFG Act') states that a

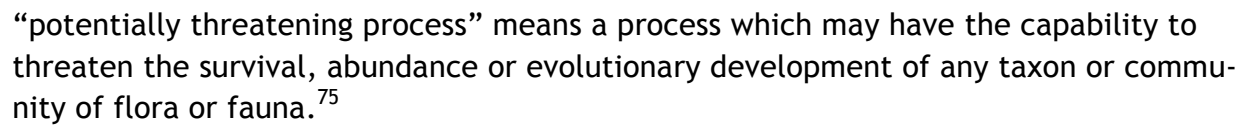

Listing of a PTP occurs pursuant to s 11 of the FFG Act and sch 1 of Flora and Fauna Guarantee Regulations 1991. In September 2000, the Scientific Advisory Committee drew the following conclusions (against the criteria set out in the sch) in its Final Recommendation on a Nomination for Listing:

\section{Evidence that criteria are satisfied:}

Criterion 5.1 The potentially threatening process, in the absence of appropriate management, poses or has the potential to pose a significant threat to the survival of a range of flora or fauna.

Evidence:

\footnotetext{
${ }^{68}$ A B Hingston and P B McQuillan, 'Does the Recently Introduced Bumblebee Bombus terrestris (Apidae) Threaten Australian Ecosystems?' (1998) 23 Australian Journal of Ecology 539. Hingston, et al, above n 10, 162-172.

${ }^{69}$ J C Stout, A R Kells, D Goulson 'Pollination of the Invasive Exotic Shrub Lupinus arboreus (Fabaceae) by Introduced Bees in Tasmania' (2002) 106 Biological Conservation 425-434.

${ }^{70}$ C.L. Gross and D. Mackay, 'Honeybees Reduce Fitness in the Pioneer Shrub Melastoma affine (Melastomataceae)' (1998) 86 Biological Conservation 169.

${ }^{71}$ C.L Gross, 'The Effect of Introduced Honeybees on Native Bee Visitation and Fruit-Set in Dillwynia juniperina (Fabaceae) in a Fragmented Ecosystem' (2001) 102 (1) Biological Conservation, 89, 89-95.

72 Simpson et al, above n 13, 541-548.

${ }^{73}$ In NSW the "Introduction of the Large Earth Bumblebee, Bombus terrestris (L.)," was listed as a KTP in Schedule 3 of the Threatened Species Conservation Act 1995 (NSW) in 2004, following a Final Determination made in Nov 2002. Listing of key threatening processes is provided for by Part 2 of the Threatened Species Conservation Act. In Victoria, "The introduction and spread of Large Earth Bumblebee B. terrestris into Victorian terrestrial environments" was listed as a Potentially Threatening Process in Victoria in September 2000 using provisions in the Flora and Fauna Guarantee Act 1988 (Vic).

${ }^{74}$ Advice to the Minister for Environment and Heritage from the Threatened Species Scientific Committee on a Public Nomination of a Key Threatening Process under the Environment Protection and Biodiversity Conservation Act 1999 'Changes to Plant-Pollinator Associations Caused by bumblebees, Bombus spp <http://www.environment.gov.au/biodiversity/threatened/ktp/bumblebees.html>

${ }^{75}$ FFG Act 1988 (Vic) s 3(1).
} 
Bumblebees may compete for resources with nectarivorous birds (honeyeaters eg. Regent Honeyeater and Helmeted Honeyeater), specialised parrots (lorikeets and the endangered Swift Parrot Lathamus discolor), some native mammals (Pygmy-possum and Sugar Glider) and endemic bees, thus reducing the reproductive output of these native flower-loving fauna. Foraging of bumblebees could lead to a reduction in seed set of native plants through nectar competition with their specialised pollinators. Bumblebee visitation to exotic plants may also lead to an increase of the number of weed species and proliferation of these species in the state.

Sub-criterion 5.1.1 The potentially threatening process, in the absence of appropriate management, poses or has the potential to pose a significant threat to the survival of two or more taxa.

Evidence:

The Regent Honeyeater (critically endangered), Helmeted Honeyeater (endangered), Black-eared Miner (critically endangered) and the Swift Parrot (endangered) are FFGlisted species which may be affected by the introduction of the bumblebee to Australia through resource competition.

Sub-criterion 5.2 The potentially threatening process poses or has the potential to pose a significant threat to the evolutionary development of a range of flora and fauna.

\section{Evidence:}

The potential threat to survival of species, as well as the potential to alter the foraging habits of flower-loving species could influence the evolutionary development of several taxa and communities.

The Minister ${ }^{76}$ adopted this recommendation under s 16 of the Act and so 'Introduction of the Bumblebee' entered the PTP list. $^{77}$

\section{Could the precautionary principle have a practical impact through the consequences of listing?}

The main consequence of listing the introduction and spread of the Large Earth Bumblebee as a PTP under the FFG Act would lie in the action plan required as a result of the listing. ${ }^{78}$ There is now a draft Flora and Fauna Guarantee Action Statement for the 'Introduction and spread of the Large Earth Bumblebee Bombus terrestris into Victorian terrestrial environments'. As mentioned above, it states that a 'precautionary approach to the introduction of bumblebees must be taken'. It makes the long term objective to be to 'Prevent Large Earth bumblebees from establishing in Victoria'"79 and includes developing legislation to 'facilitate entry to private property to search for invertebrates'. ${ }^{80}$ The language and approach of the draft Action Plan are certainly consistent with the precautionary principle, even if the FFG Act does not require it. There is other action under the FFG Act, such as the making of an interim conservation order under ss 26 and 27, which might prevent introduction of bumblebees but it does not automatically follow the PTP listing. The PTP listing may only make it easier to establish that such action should

\footnotetext{
${ }^{76}$ Strictly, recommended to the Governor-in-Council.

77 Department of Environment and Sustainability Flora and Fauna Guarantee Act 1988 Processes List April 2006 <http://www.dse.vic.gov.au/CA256F310024B628/0/77D3B8F238C8A7B1CA2571460020E72F/ \$File/FFG+processe s+list+april+2006.pdf >

78 'Introduction of the Large Earth Bumblebee' listed on the website 'Flora and Fauna Guarantee - Draft Action Plans for Public Comment', see http://www.dse.vic.gov.au/DSE/nrenpa.nsf/LinkView/ 69770772A2A1F48BCA256FB300073432E7A24BB36FF60A144A256DEA00244294. (The Department of Primary Industry also has a 'Keep Victoria Bumblebee Free' website, see <http://www.dpi.vic.gov.au/dpi/nreninf.nsf/LinkView/823E3E9A7566B26CCA256C40001AE6A3 A5F56BB1473442224A256DEA00282268>

79 Ibid, 4.

${ }^{80}$ Ibid, 5.
} 
occur. ${ }^{81}$ Despite the lack of legislative reference in Victoria, there is something to suggest that the precautionary principle could have a practical impact through the consequences of listing bumblebees as a threatening process.

\section{The New South Wales listing}

In New South Wales, a KTP is a process within an ecosystem that jeopardises the existence of a specific biotic component in that ecosystem. This is defined under s 13 of the Threatened Species Conservation Act 1995 (NSW) ('TSC Act') to include species, populations and ecological communities that are or could become threatened with extinction:

13 Threatening processes eligible for listing as key threatening processes

(1) A threatening process is eligible to be listed as a "key threatening process" if, in the opinion of the Scientific Committee:

(a) it adversely affects threatened species, populations or ecological communities, or

(b) it could cause species, populations or ecological communities that are not threatened to become threatened.

Pursuant to the Threatened Species Conservation Act, ${ }^{82}$ the 2004 Final Determination of the Scientific Committee on Introduction of the Large Earth Bumblebee concludes:

8. Species and populations in NSW that may become threatened by the presence of Large Earth bumblebees promoting the spread of Scotch Broom include endangered species Epacris hamiltonii, the Bathurst Copper Paralucia spinifera, the Ben Halls Gap National Park Sphagnum Moss Cool Temperate Rainforest Endangered Ecological Community, and the vulnerable terrestrial orchid Chiloglottis platyptera.

9. In view of the above the Scientific Committee is of the opinion that the introduction of the Large Earth Bumblebee, Bombus terrestris, could cause species or populations that are not threatened to become threatened. ${ }^{83}$

The decision to list a KTP rests with the Scientific Committee under ss 23 and 24, although the Minister may ask the Committee to give it further consideration. ${ }^{84}$

\section{Could the precautionary principle have a practical impact through the consequences of listing?}

A direct consequence of listing could be the implementation of a Threat Abatement Plan ('TAP'), although it is within the discretion of the Director-General of the Department of Environment and Climate Change as to whether to prepare such a plan. ${ }^{85}$ There is as yet no TAP for bumblebees. Even if there were such a plan it would not necessarily have a direct effect on the tomato growing industry because TAPs only directly bind other government

\footnotetext{
${ }^{81}$ Under the Planning and Environment Act 1987 (Vic), the use of bumblebees to pollinate tomatoes does not appear to be regarded as a development, which relates to structures rather than activities. This Act would not therefore appear to regulate such an activity.

${ }^{82}$ Threatened Species Conservation Act 1995 s 23.

${ }^{83}$ See <http://www.nationalparks.nsw.gov.au/npws.nsf/PrintFriendly/Bombus_terrestris_ktp_declaration>. For a critique of the effectiveness of listing under the Threatened Species Conservation Act see Garth Riddell 'A Crumbling Wall - The Threatened Species Conservation Act 10 Years On' (2005) 22 Environmental and Planning Law Journal 446, 451- 453; and, generally, Andrew Kelly and James Prest 'Implementation of Threatened Species Law by Local Government in New South Wales' (2000) 17(6) Environmental and Planning Law Journal, 584.

${ }^{84}$ Threatened Species Conservation Act s 23A.

${ }^{85}$ Threatened Species Conservation Act s 74.
} 
agencies and even then with significant provisos. ${ }^{86}$ There is no example yet of a TAP that seeks to prevent the introduction of a threatening species into New South Wales. ${ }^{87}$

In the absence of a TAP, another consequence of the KTP determination could relate to gaining approval under the Environmental Planning and Assessment Act 1979 (NSW) ('EPAA') for the use of bumblebees to pollinate tomatoes. This Act requires a species impact statement to accompany an application for development ${ }^{88}$ or approval of activity ${ }^{89}$ which 'is likely to significantly affect threatened species, populations or ecological communities'.$^{90}$ In this case the Scientific Committee Determination clearly does identify species and ecological communities which may be threatened by bumblebees so a species impact statement should be required. The Director-General would also need to concur with the development or approval of the activity and in doing so take account of, among other things, the species impact statement, any TAP and the principles of ESD..$^{91}$ The precautionary principle could have a practical impact on the issue of bumblebees, then, through some of the consequences of listing.

\section{Has the precautionary principle affected the State decisions?}

There is nothing in the Determinations of the respective State scientific committees that makes clear that they have considered the precautionary principle. It is clear though that they have applied the respective specific statutory provisions on listing bumblebees as a threatening process. It may be that the threatening process provisions are particular expressions of the precautionary principle and applying them is evidence of a precautionary approach. As Mahoney stated with respect to the Threatened Species Conservation Act, 'The criteria for listing of threatening processes ... is an indication that in a small way precautionary pre-emptive measures are being given statutory recognition'. ${ }^{92}$

Certainly, the use of language such as 'potentially threatening' and 'significant threat' to 'survival' or 'evolutionary development' of flora and fauna in the Victorian decision reflects the 'threats of serious or irreversible environmental damage' language of the precautionary principle, or an approach consistent with it. So too, the use of terms such as 'threatened', 'endangered' and 'vulnerable' and 'could cause species or populations that are not threatened to become threatened' in the New South Wales decision also reflects the language of the principle or an approach consistent with it. Arguably, the precautionary principle has affected the State listings though in an indirect way.

\footnotetext{
${ }^{86}$ Threatened Species Conservation Act s 86. See discussion in David Farrier 'Fragmented Law in Fragmented Landscapes: the Slow Evolution of Integrated Natural Resource Management Legislation in NSW' (2002) 19(2) Environmental and Planning Law Journal 89, 104.

${ }^{87}$ The three final TAPs in place to date deal with threatening species already in New South Wales, ie bitou bush, plague minnows and the red fox. See <http://www.nationalparks.nsw.gov.au/npws.nsf/Content/

Threat+abatement+plans+by+doctype>

${ }^{88}$ This would assume that using bumblebees to pollinate tomatoes met the definition of development under Environmental Planning and Assessment Act 1979 s 4 as a use of land or through being controlled by an environmental planning instrument.

89 This would assume that using bumblebees to pollinate tomatoes met the definition of an activity under Environmental Planning and Assessment Act 1979 s 110 as a use of land. It also assumes that a private interest, rather than a government agency, would make an application to use bumblebees for pollination. The provisions discussed here have slightly different requirements for activities of government agencies.

${ }^{90}$ Environmental Planning and Assessment Act $1979 \mathrm{~s} 78 \mathrm{~A}(8)(\mathrm{b})$ or s 112(1). The species impact statement must be prepared in accordance with div 2 of pt 6 of the Threatened Species Conservation Act.

${ }^{91}$ Environmental Planning and Assessment Act 1979 s 79B, for a development, or s 112C, for approval of an activity. See discussion in Farrier 'Fragmented Law in Fragmented Landscapes: the Slow Evolution of Integrated Natural Resource Management Legislation in NSW', above n 86, 98, 102-104.

92 Mahoney, above $\mathrm{n} 43,13$. Preston CJ also saw a clear link between the precautionary principle and threatened species provisions in Bentley $v$ BGP Properties Pty Limited [2006] NSWLEC 34, para 68. Riddell, above n 83, 449. on the other hand, also with respect to New South Wales, observed that, 'Perhaps the most telling criticism of the TSCA is that it provides procedural rather than substantive protection. Such an approach fails to implement the precautionary principle ...'
} 


\section{The decision of the Commonwealth not to list}

\section{Section 188 of the EPBC Act defines a KTP as follows:}

(3) A process is a threatening process if it threatens, or may threaten, the survival, abundance or evolutionary development of a native species or ecological community.

(4) A threatening process is eligible to be treated as a key threatening process if:

(a) it could cause a native species or an ecological community to become eligible for listing in any category, other than conservation dependent; or

(b) it could cause a listed threatened species or a listed threatened ecological community to become eligible to be listed in another category representing a higher degree of endangerment; or

(c) it adversely affects 2 or more listed threatened species (other than conservation dependent species) or 2 or more listed threatened ecological communities.

If the Commonwealth Threatened Species Scientific Committee makes a recommendation to the Minister, the Minister must consider that advice ${ }^{93}$ and decide whether or not to list the process as a KTP. ${ }^{94}$ The Committee had the benefit of the Victorian and New South Wales Scientific Committees' reports. Even so, its final recommendation acknowledged a potential threat but not enough of one to recommend listing 'Changes to plant-pollinator associations caused by Large Earth bumblebees, Bombus terrestris' as a KTP:

\section{Recommendations}

C. The Committee regards the introduction of any exotic species as a potential environmental risk, noting that in Tasmania, the bumblebee has become widespread in both modified and natural systems. However, on the data available, insufficient impact has been detected, and therefore the Committee recommends that the threatening process cannot be listed at this time. The Committee urges that extreme caution be shown in considering any proposal to introduce this species to the mainland. In taking this position, it highlights the concern that many native species are dependent on native pollinators, so it could potentially be a threat in the future.

This recommendation raises questions about when the precautionary principle could be triggered if the Committee was required to consider it. The recommendation states that 'insufficient impact has been detected" 95 for a listing 'at this time', which indicates that the Committee did not see the precautionary principle as being triggered at that stage. The Committee appeared concerned with the threat of bumblebees reaching the mainland, rather than the threat they would pose should they do so. This may explain the divergence between the approach of the Commonwealth and that of New South Wales and Victoria. It would be contrary to the precautionary principle, though, for the Commonwealth Committee to decline to list 'on the data available' when the principle would apply in situations of scientific uncertainty. If there is a 'threat of serious or irreversible damage', which the Committee appeared to acknowledge there could be if bumblebees

\footnotetext{
${ }^{93}$ EPBC Act s 189.

${ }^{94}$ EPBC Act s 188.

${ }^{95}$ For available data see A B Hingston, 'Is the Exotic Bumblebee, Bombus terrestris (Apidae), Really Invading Tasmanian Native Vegetation? (2006) 10(3) Journal of Insect Conservation 289; A B Hingston, W Herrmann, G J Jordan 'Reproductive Success of a Colony of the Introduced Bumblebee Bombus terrestris (L.) (Hymenoptera: Apidae) in a Tasmanian National Park' (2006) 45 Australian Journal of Entomology 137. A B Hingston, 'Inbreeding in the Introduced Bumblebee Bombus terrestris Causes Uncertainty in Predictions of Impacts on Native Ecosystems' (2005) 6 Ecological Management and Restoration, 151-153; A B Hingston 'Does the Introduced Bumblebee, Bombus terrestris (Apidae), Prefer Flowers of Introduced or Native Plants in Australia? (2005) 53 Australian Journal of Zoology, 29.
} 
reached the mainland, then a lack of further data should not have been a reason to decline to act. On the other hand, the recommendation certainly left open an invocation of the precautionary principle with respect to the proposal to import bumblebees to the mainland. The words 'urges that extreme caution be shown' could hardly be more suggestive of this. The main conclusion to draw, though, on the Commonwealth Committee's recommendation is that it was not bound to apply the precautionary principle and there is little to suggest any impact of it on the recommendation.

\section{Could the precautionary principle have a practical impact through the consequences of listing?}

It is interesting to note that if the Commonwealth Committee had listed bumblebees as a KTP, as was done in New South Wales, the Minister would have had discretion as to whether to have a TAP prepared. ${ }^{96}$ The Minister would have been required to take the precautionary principle into account in deciding whether or not to have a TAP. ${ }^{97}$ If the Minister did decide to have a TAP, there are provisions which would have compelled the Commonwealth to implement it and to refrain from taking action to contravene it. ${ }^{98}$ Would a decision not to have a TAP in itself be contrary to the precautionary principle? On the words of the principle ${ }^{99}$ this would only be if the reason for 'postponing measures' was a 'lack of full scientific certainty'. Under s 270A, the grounds upon which a Minister must decide to have, or not have, a TAP are if it is a 'feasible, effective and efficient' way to abate the threatening process. To be able to argue that a decision not to have a TAP was contrary to the precautionary principle, 'a lack of full scientific certainty' would have to be part of the reason a plan would not be 'feasible, effective and efficient'. Even so, had the Commonwealth listed bumblebees as a threatening process, the precautionary principle could then have had a practical impact on preventing environmental degradation.

\section{What Does This Say About the precautionary principle?}

This situation illustrates that the broad incorporation of the precautionary principle in policy, legislation and case law in Australia does not mean that the principle must be a part of decision making on listing threatening processes. Even if it was, it would still not necessarily be applied in the same way, or at all, even on essentially the same information. ${ }^{100}$ It was arguably legitimate for the Commonwealth committee to have reached its conclusion, if it was applying the precautionary principle, on the basis that bumblebees do not actually pose a threat, or, if they do, that it is not serious. ${ }^{101}$ (Though, given the experience in Tasmania, it is probably not arguable that an invasion of bumblebees would be reversible.) It is also arguable that the precautionary principle could have had no decisive effect in the Commonwealth committee's decision in spite of the available science, and that the need for more evidence of impact would have been contrary to the precautionary principle. ${ }^{102}$ As Preston CJ put it in Telstra v Hornsby Shire Council:

\footnotetext{
${ }^{96}$ EPBC Act s 269AA.

97 EPBC Act s $270 \mathrm{~A}$

${ }^{98}$ EPBC Act ss $268 \& 269$.

${ }_{99}$ As stated in s 391(2) of the EPBC Act.

100 As Peterson notes, above $\mathrm{n} 17,483$, how to treat incomplete scientific information remains a problematic question under most formulations of the precautionary principle.

101 See discussion in Peel, above n 19, 63-67. Warwick Gullett considers Australian cases on the threshold of application of the precautionary principle, which variously set high and low thresholds, in 'The Threshold Test of the Precautionary Principle in Australian Courts and Tribunals: Lessons for Judicial Review' in Fisher, Jones and von Schomberg (eds), above n 15, 182, 190-193. Justice Stein's view was that, in determining proof of threat, 'the principle fails to offer any clear guidance in respect of what degree of proof is required before the principle becomes operational ... [although] ... in a legal setting, the civil standard of proof on the balance of probabilities is apposite. Stein, above $n 17,6$.

${ }^{102}$ See Peel, above n 19, 74-75.
} 
Determining the existence of a threat of serious or irreversible environmental damage does not involve, at the stage of assessing the first condition precedent, any evaluation of the scientific uncertainty of the threat. That evaluation comes in the following steps of analysis. ${ }^{103}$

With regard to the states, it was also legitimate for the New South Wales and Victorian committees to have applied the precautionary principle on the basis that bumblebees would pose a threat of serious or irreversible harm to the environment in each state. ${ }^{104}$

\section{The application to import the large earth bumblebee, Bombus Terrestris L. to the mainland}

While the Commonwealth Committee did not recommend bumblebees be listed as a KTP under the EPBC Act, as stated above, it 'urges that extreme caution be shown in considering any proposal to introduce this species to the mainland.' Such language suggests the relevance of the precautionary principle to the application to import bumblebees to mainland Australia.

The Australian Hydroponic and Greenhouse Association (AHGA) sought the importation of bumblebees to mainland Australia to facilitate the pollination of crops, particularly greenhouse tomatoes Solanum lycopersicum. ${ }^{105}$ The EPBC Act regulates importation to Australia of all species of plants and animals. ${ }^{106}$ A regulated live specimen is a live plant or live animal that is not on the list of specimens approved for import. ${ }^{107}$ The Bumblebee was not on the list of specimens approved for import made under s $303 \mathrm{~EB}^{108}$ and was therefore a regulated live specimen. It is an offence to import a regulated live specimen without a permit. ${ }^{109}$ Under s $303 E$ a person can apply for an amendment to the list of regulated live specimens:

(1) A person may, in accordance with the regulations, apply to the Minister for the list referred to in section 303EB to be amended by including an item.

(2) The Minister must not consider the application unless:

(a) an assessment is made of the potential impacts on the environment of the proposed amendment; and

(b) a report on those impacts is given to the Minister.

The report must be prepared in accordance with section 303EF. ${ }^{110}$

${ }^{103}$ Telstra v Hornsby Shire Council [2006] NSWLEC 133, paras 137-138, citing N de Sadeleer, Environmental Principles: From Political Slogans to Legal Rules (Oxford University Press, 2005) 163.

104 This difference of view reflects the divergence noted by Gullett (2006), above $n$ 101, between needing no evidence of a threat of serious or irreversible damage on the one hand, and needing credible evidence of a threat on the other.

${ }^{105}$ Australian Hydroponic \& Greenhouse Association Proposal to Import Bombus terrestris (Bt) onto Mainland Australia for Crop Pollination Purposes (December 2005) <http: / /www.environment.gov.au/biodiversity/tradeuse/invitecomment/pubs/bombus-terrestris.pdf>; See also S Carruthers 'Editorial' (2003) 69 Practical Hydroponics and Greenhouses, 24; S Carruthers 'Editorial' (2004) 77 Practical Hydroponics and Greenhouses, 24.

${ }^{106}$ Chapter 5 Conservation of biodiversity and heritage, Part 13A International movement of wildlife specimens, Division 4 Imports of regulated live specimens.

${ }^{107}$ EPBC Act 1999 s 303EA. This Act does not appear to distinguish between animals and insects in the definition of animal in s 528 (the definitions section) or in this part of the Act. There is only a distinction, perhaps curiously, between the animal kingdom and the plant kingdom, therefore a bee is treated as an animal.

${ }^{108}$ The list may be found at <http://www.environment.gov.au/biodiversity/trade-use/lists/import/pubs/liveimport-list.pdf>

${ }^{109}$ EPBC Act 1999 s 303EK.

${ }^{110}$ The Minister must decide on the proposed amendment within 30 business days of receiving the report, unless the Minister specifies a longer time. Public comment on the draft report closed on 16 June 2006 in accordance with s $303 \mathrm{EF}$. See <http://www.deh.gov.au/biodiversity/trade-use/invitecomment/index.html>. Section 303 EF states that the assessment must provide for the following:

(a) the preparation of draft terms of reference for a report on the relevant impacts; and

(b) the publication of the draft terms of reference for public comment for a period of at least 10 business days that is specified by the Minister; and

(c) the finalisation of the terms of reference, to the Minister's satisfaction, taking into account the comments (if any) received on the draft terms of reference; and 
The argument of the proponents is perhaps best summarised in the conclusion to the Executive Summary of the Proposal to Import:

The AHGA is entirely satisfied that certified clean stock can safely be brought to the Australian mainland for pollination of greenhouse crops as evidenced by its safe use around the world in 36 countries on over 25 crops.

None of the 36 countries currently enjoying bumblebee technology report substantiated claims of deleterious effects on their local flora or fauna. $\left.{ }^{[111}\right]$ This fact is entirely at odds with claims by Australian opposition groups that "all hell will break loose" if bumblebees areallowed to leave Tasmania for the mainland. Good science must be allowed to prevail.

Australian growers are actively competing with imported products from other countries with access to bumblebee technology. This enormous disadvantage is reflected in our farms' viability and competitiveness. Bumblebees not only save substantial costs for necessary pollination of crops, they are also much more efficient and effective in this role leading to higher returns for Australian farmers. Commercial realities must be seriously considered.

"If one considers all the facts given, then the case is clearly made to permit the commercial introduction of Bombus terrestris onto mainland Australia"

(D. Griffiths 2004, previously identified critical study) ${ }^{112}$

\section{Provisions Governing the Minister's Decision}

The only government decision maker specifically required to consider the precautionary principle on this question was the Minister under s 391 of the EPBC Act, which specifies that the principle must be considered in issuing permits for regulated live specimens under s $303 \mathrm{EN}$. Notably, this requirement applies to the Minister 'to the extent he or she can do so consistently with the other provisions of this Act'. ${ }^{113}$

It appears that the Minister has applied the precautionary principle, although using the term 'precautionary approach'. He mentioned in his media release that there is evidence that importation of bumblebees to mainland Australia poses a 'serious risk' and could 'have serious environmental consequences'. He also touched on there being a lack of full scientific certainty on the safety of importation given that bumblebees have escaped from greenhouses in Japan and Israel. The media release refers directly to the decisions of Victoria and New South Wales. ${ }^{114}$ The Minister also made clear that he relied on scientific evidence and advice. Although this does not seem to have been published, the recommen-

(d) the preparation of a draft of a report on the relevant impacts; and

(e) the publication of the draft report for public comment for a period of at least 20 business days that is specified by the Minister; and

(f) the finalisation of the report, taking into account the comments (if any) received after publication of the draft report; and

(g) any other matter prescribed by the regulations.

111 It is important to note that this claim is disputed. The authors of this paper have found ample literature on the ecological impact of escaped bumblebees from commercial greenhouses overseas; see for example T Kenta, $\mathrm{N}$ Inari, T Nagamitsu, K Goka, T Hiura, 'Commercialized European Bumblebee Can Cause Pollination Disturbance: An Experiment on Seven Native Plant Species in Japan' (2007) 134(3) Biological Conservation 298; K Goka, K Okabe, M Yoneda, 'Worldwide Migration of Parasitic Mites as a Result of Bumblebee Commercialization' (2006) 48(4) Population Ecology 285; N Inari, Nagamitsu, T Kenta, K Goka, T Hiura, 'Spatial and Temporal Pattern of Introduced Bombus terrestris Abundance in Hokkaido, Japan, and its Potential Impact on Native Bumblebees (2005) 47(1) Population Ecology 77; D Goulson, 'Keeping Bees in Their Place: Impacts of Bees Outside Their Native Range (2004) 85(3) Bee World 45; and D Goulson, 'Effects of Introduced Bees on Native Ecosystems' (2003) 34 Annual Review of Ecology Evolution and Systematics 1.

112 Australian Hydroponic and Greenhouse Association Proposal to Import Bombus terrestris (Bt) onto Mainland Australia for Crop Pollination Purposes (December 2005), above n 105, vii.

${ }^{113}$ EPBC Act s 391(1).

${ }^{114}$ The Minister should have discussed the permit application with the governments of New South Wales and Victoria under s303ED(3)b; '[the Minister] must consult such other Minister or Ministers of each State and self governing Territory as the Minister considers appropriate'. 
dation of the Commonwealth Scientific Committee which 'urges that extreme caution be shown' on the question of importing bumblebees to the mainland should have been significant. ${ }^{115}$ Further, since the Commonwealth Scientific Committee's recommendation there has been new science on alternatives to pollination by bumblebees and evidence that commercial bumblebees readily escape and cause ecological harm. ${ }^{116}$

\section{CONCLUSION}

The potential adverse consequences of introducing the Bumblebee would appear to invoke the questions posed by the precautionary principle:

The precautionary principle is that lack of full scientific certainty should not be used as a reason for postponing a measure to prevent degradation of the environment where there are threats of serious or irreversible environmental damage (s 391(2) EPBC Act)

This paper is a case study of the variable impact of the precautionary principle despite its broad acceptance in policy, legislation and caselaw. While it might be expected to have an impact on the question of introducing bumblebees, the relevant legislation does not consistently require consideration of the principle. The biodiversity conservation focus of the various listing provisions seems to have rendered the precautionary principle formally not a factor to take into consideration, even though theoretically it should be highly relevant to conserving biodiversity. There is evidence, though, that the Victorian and New South Wales committees have taken an approach consistent with the precautionary principle, and it might be argued that the listing provisions themselves in some way reflect a precautionary approach.

Even so, the practical impact of the precautionary principle is patchy at best. In Victoria the draft TAP for bumblebees takes a precautionary approach and there are some limited other consequences of listing that might prevent bumblebees causing degradation to the environment. In New South Wales there is no TAP for bumblebees at this stage. Still, should there have been steps towards using bumblebees in horticulture, the possible requirement for species impact statements and Director-General concurrence, taking into account ESD principles, means that there might be 'measures to prevent degradation of the environment ${ }^{117}$ in the face of the potential threat of bumblebees. The Commonwealth committee on the other hand is not bound to apply the precautionary principle and its recommendation on listing bumblebees was not consistent with it. Given the different conclusions on the same information, the 'common sense, 118 of the precautionary principle did not seem common. ${ }^{119}$ Ironically, if the Commonwealth did list bumblebees as a KTP, the precautionary principle would have been a mandatory consideration in deciding whether to have a TAP. Further, if there was such a plan, the implementation requirements of the legislation are relatively strong. The only decision maker explicitly bound to

\footnotetext{
${ }^{115}$ It should also be significant that native bee alternatives for the horticulture industry are currently being domesticated, as greenhouse studies have shown that Australian blue banded bees are able to pollinate tomatoes to levels comparable with bumblebee pollination. In time there may be a local solution to the pollination services demanded by the horticultural industry, see K Hogendoorn, S Coventry and M A Keller 'Foraging Behaviour of a Blue Banded Bee, Amegilla chlorocyanea in Greenhouses: Implications for Use as Tomato Pollinators' (2007) 38(1) Apidologie 86; K Hogendoorn. C L Gross, M Sedgley, M A Keller, 'Increased Tomato Yield Through Pollination by Native Australian Amegilla chlorocyanea (Hymenoptera: Anthophoridae)' (2006) 99(3) Journal of Economic Entomology 828; M C Bell, R N Spooner-Hart, M Haigh 'Pollination of Greenhouse Tomatoes by the Australian Bluebanded Bee Amegilla (Zonamegilla) holmesi (Hymenoptera: Apidae)' (2006) 99(2) Journal of Economic Entomology 437.

${ }^{116}$ See notes 111 and 115 above.

117 EPBC Act 1999 s $391(2)$.

118 Leatch v National Parks and Wildlife Service (1993) 81 LGERA 270 per Stein J.

119 Whelan et al, above $n$ 44, and references therein, highlight that the obscure construction of the precautionary principle, with the multiple use of negatives, limits its power, and observe that the principle is often misunderstood. We concur.
} 
consider the precautionary principle with regard to bumblebees has been the Commonwealth Minister. This is only in regard to importation. The Minister clearly took the principle into account, giving strong reasons why it should apply so as not to allow importation.

The overall result has been to prohibit bumblebees from entering mainland Australia although the formal role of the precautionary principle in this outcome seems to have been quite variable. The precautionary principle appears to have been decisive with respect to the Commonwealth Minister's decision on importation, discernible but elusive in respect of state approaches and absent from the Commonwealth threatening process decision. This does not reflect its broad acceptance in Australian policy, legislation and case law. It seems that the precautionary principle can be as elusive as it is pervasive. 